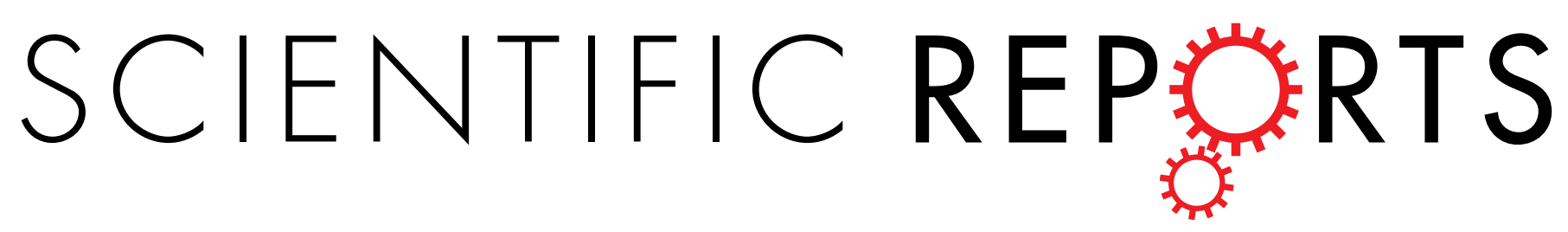

OPEN Author Correction: N-terminal

\title{
gelsolin fragment potentiates TRAIL mediated death in resistant hepatoma cells
}

Keith Meyer ${ }^{1}$, Young-Chan Kwon ${ }^{1}$, Ratna B. Ray ${ }^{2}$ \& Ranjit Ray ${ }^{1}$

Correction to: Scientific Reports https://doi.org/10.1038/s41598-017-13131-7, published online 09 October 2017

In Figure 2D, the blot for 'p-Erk (T202/Y204)' is missing. The correct Figure 2 appears below as Figure 1. 
A
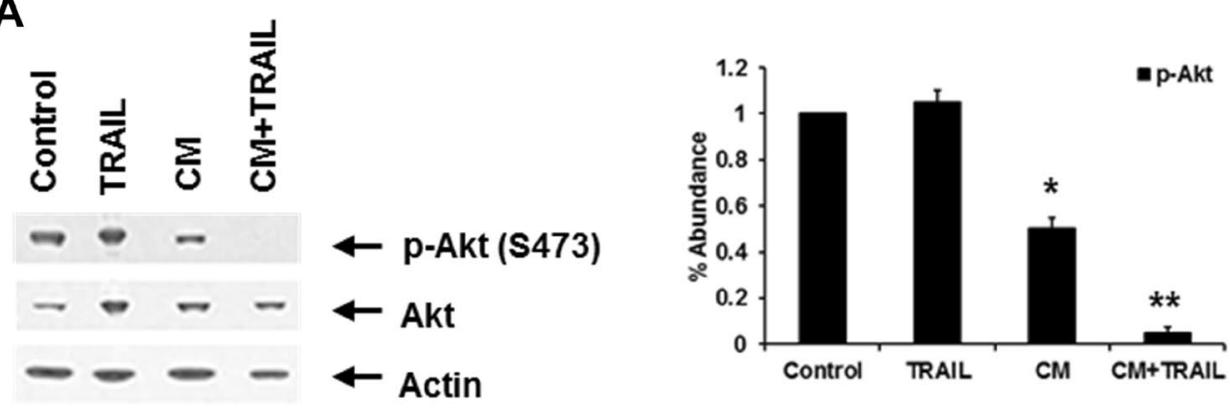

B
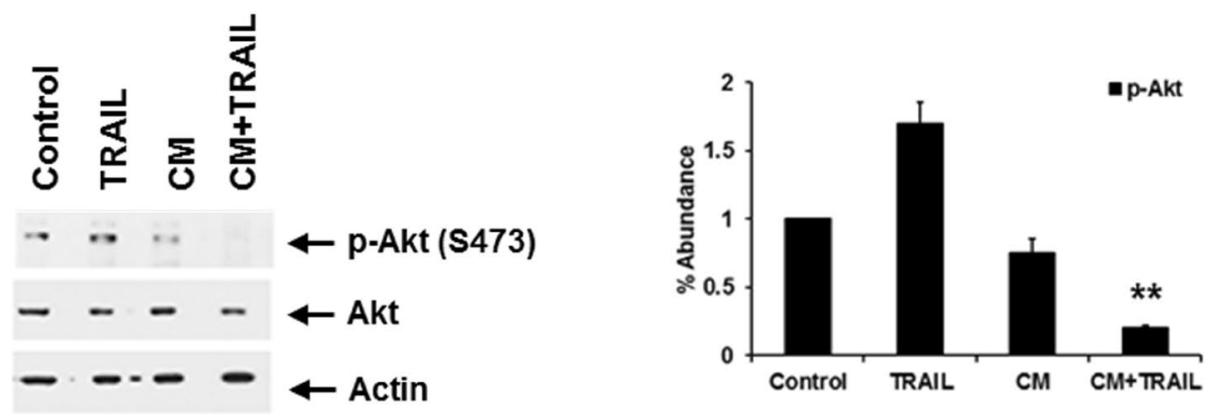

C
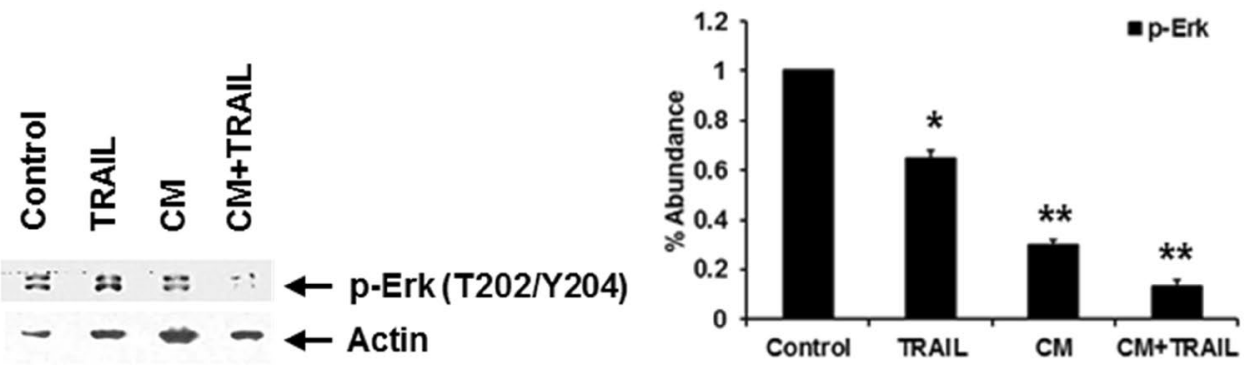

D
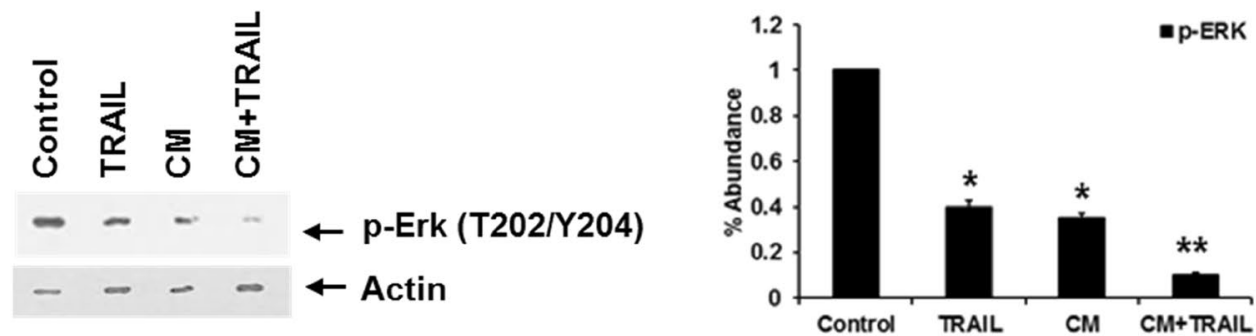

Figure 1. CM in association with TRAIL inhibits Akt and Erk activation. Akt and Erk activation was analyzed in HepG2 (panels A and C) and Huh7 (panels B and D) cells. CM was added on cells 24 hours prior to the addition of TRAIL. Densitometric scan data is provided. Each panel is representative of three independent experiments. Note that cropped gel images are used and the gels were run under the same experimental conditions.

Open Access This article is licensed under a Creative Commons Attribution 4.0 International License, which permits use, sharing, adaptation, distribution and reproduction in any medium or format, as long as you give appropriate credit to the original author(s) and the source, provide a link to the Creative Commons license, and indicate if changes were made. The images or other third party material in this article are included in the article's Creative Commons license, unless indicated otherwise in a credit line to the material. If material is not included in the article's Creative Commons license and your intended use is not permitted by statutory regulation or exceeds the permitted use, you will need to obtain permission directly from the copyright holder. To view a copy of this license, visit http://creativecommons.org/licenses/by/4.0/. 